\title{
Luteinizing hormone-induced Akt phosphorylation and androgen production are modulated by MAP Kinase in bovine theca cells Shin Fukuda ${ }^{1}$, Makoto Orisaka*1,2, Kimihisa Tajima1 ${ }^{1}$, Katsushige Hattori ${ }^{1}$ and Fumikazu Kotsuji ${ }^{1}$
}

\author{
Address: ${ }^{1}$ Department of Obstetrics \& Gynecology, University of Fukui, Matsuoka, Fukui, 910-1193, Japan and 2University of Fukui, 23-3 \\ Shimoaiduki, Matsuoka, Eiheiji-cho, Yoshida-gun, Fukui, 910-1193, Japan \\ Email: Shin Fukuda - sfukuda@u-fukui.ac.jp; Makoto Orisaka* - orisaka@u-fukui.ac.jp; Kimihisa Tajima - kimihisa@fukui-med.jrc.or.jp; \\ Katsushige Hattori - kahatton@u-fukui.ac.jp; Fumikazu Kotsuji - kotsujif@u-fukui.ac.jp \\ * Corresponding author
}

Published: 16 November 2009

Journal of Ovarian Research 2009, 2:17 doi:10.1186/1757-2215-2-17

Received: 13 July 2009

Accepted: 16 November 2009

This article is available from: http://www.ovarianresearch.com/content/2/1/17

(C) 2009 Fukuda et al; licensee BioMed Central Ltd.

This is an Open Access article distributed under the terms of the Creative Commons Attribution License (http://creativecommons.org/licenses/by/2.0), which permits unrestricted use, distribution, and reproduction in any medium, provided the original work is properly cited.

\begin{abstract}
Background: Theca cells play an important role in controlling ovarian steroidogenesis by providing aromatizable androgens for granulosa cell estrogen biosynthesis. Although it is well established that the steroidogenic activity of theca cells is mainly regulated by $\mathrm{LH}$, the intracellular signal transduction mechanisms that regulate thecal proliferation and/or steroidogenesis remain obscure. In this study, we examined whether and how LH controls the PI3K/Akt signaling pathway and androgen production in bovine theca cells. We also explored whether this LH-induced PI3K/ Akt activation is modulated with other signaling pathways (i.e. PKA and MAPK).
\end{abstract}

Methods: Ovarian theca cells were isolated from bovine small antral follicles and were incubated with $\mathrm{LH}$ for various durations. Phospho-Akt and total-Akt content in the cultured theca cells were examined using Western blotting. Androstenedione levels in the spent media were determined using EIA. Semi-quantitative RT-PCR analyses were conducted to analyze the mRNA levels of CYPI7AI and StAR in the theca cells. To examine whether Akt activity is involved in theca cell androgen production, the PI3K inhibitors wortmannin and LY294002 were also added to the cells.

Results: Akt is constitutively expressed, but is gradually phosphorylated in cultured bovine theca cells through exposure to $\mathrm{LH}$. LH significantly increased androstenedione production in bovine theca cells, whereas addition of the wortmannin and LY294002 significantly decreased LH-induced androstenedione production. LH significantly increased CYPI7AI mRNA level in theca cells, whereas addition of LY294002 significantly decreased LH-induced CYPI7AI expression. Neither LH nor PI3K inhibitors alter the mRNA levels of StAR in theca cells. Although H89 (a selective inhibitor of PKA) does not affect LH-mediated changes in Akt, U0I26 (a potent MEK inhibitor) suppressed LH-induced Akt phosphorylation, CYPI7AI expression, and androgen production in theca cells.

Conclusion: These results indicate that $\mathrm{LH}$ stimulates CYPI7 mRNA expression and androgen production in theca cells via activation of the PI3K/Akt pathway. The LH-induced Akt phosphorylation and androgen production are modulated by the MAPK signaling in bovine theca cells. 


\section{Background}

The principal function of ovarian theca cells is steroid hormone production. Theca cells play an important role in controlling ovarian steroidogenesis by providing aromatizable androgens for granulosa cell estrogen biosynthesis [1]. Androgens also function as local regulators of ovarian folliculogenesis upon binding androgen receptors localized to granulosa cells, stromal cells, and oocytes [2]. Androgen receptor null mice culminate in reduced fertility and premature ovarian failure [3], indicating that androgens are necessary for reproductive function and fertility. Normal ovarian function requires accurate regulation of steroidogenic activity of theca cells through extraovarian and intraovarian mechanisms. Thecal steroidogenic hyperactivity can cause ovarian dysfunction, such as polycystic ovary syndrome (PCOS) [4].

It is well established that theca cell steroidogenesis is under the primary control of luteinizing hormone (LH) through the second-messenger cAMP-protein kinase A (PKA) pathway $[5,6]$. Moreover, LH stimulates theca cells to produce androgens and to maintain progesterone production by the induction of genes involved in steroidogenesis: cytochrome P450 side-chain cleavage enzyme (CYP11A1), 3 $\beta$-hydroxysteroid dehydrogenase, $17 \alpha$ hydroxylase/C17-20 lyase cytochrome P450 (CYP17A1), and steroidogenic acute regulatory protein (StAR) [7-10].

Intracellular signaling mechanisms that regulate ovarian follicular development and/or steroidogenesis remain obscure [11]. Nevertheless, LH reportedly activates the extracellular-signal-regulated kinases (ERK)/mitogen activated protein kinase (MAPK) pathway in ovarian granulosa and theca cells [12]. Although FSH and several growth factors are known to activate the phosphatidylinositol 3' kinase (PI3K)/Akt pathway in granulosa cells [13-15], whether LH stimulates the PI3K/Akt cascade in theca cells is not clear. Although LH augments androgen production in theca cells, it remains unknown whether this response is mediated via activation of the PI3K/Akt pathway.

In this study, we examined whether and by what means LH controls PI3K/Akt signaling and androgen production using cultured bovine theca cells. We demonstrated that LH stimulates CYP17A1 mRNA expression and androgen production in theca cells via activation of the PI3K pathway. Both the PI3K and the MAPK pathways coordinately regulate androgen production in bovine theca cells.

\section{Methods \\ Exprimental design}

Experiment I

To examine whether LH stimulates PI3K/Akt signaling in theca cells, bovine theca cells from small antral follicles were incubated with $\mathrm{LH}$ for various durations $(0,5 \mathrm{~min}$,
20 min, 1 h, 2 h, 4 h, 6 h, 8 h, 12 h, 24 h, and 48 h), and phospho-Akt and total-Akt content were examined using Western blotting.

\section{Experiment 2}

To examine whether Akt activity is involved in theca cell androgen production, theca cells were pretreated for 30 min with the PI3K inhibitors, wortmannin $(0.1 \mu \mathrm{M})$ and LY294002 $(25 \mu \mathrm{M})$. The cells were subsequently stimulated with $\mathrm{LH}(100 \mathrm{ng} / \mathrm{ml})$ for $24 \mathrm{~h}$. Androstenedione levels in the spent media were determined using EIA.

\section{Experiment 3}

Along with examining androstenedione production, semi-quantitative RT-PCR analyses were conducted to analyze the mRNA levels of CYP17A1 and StAR in the cultured theca cells at $12 \mathrm{~h}$ of incubation.

\section{Experiment 4}

Whether PKA or MAPK pathway influence LH-induced Akt phosphorylation in theca cells was explored. Theca cells were pretreated with $\mathrm{H} 89$ (i.e. a selective inhibitor of PKA [16]), and U0126 (i.e. a potent MEK inhibitor) for 30 $\mathrm{min}$. The cells were subsequently stimulated with LH (100 $\mathrm{ng} / \mathrm{ml}$ ) for $24 \mathrm{~h}$. Phospho-Akt and total-Akt content in the cultured theca cells were examined using Western blot at $24 \mathrm{~h}$ of the culture. CYP17A1 mRNA levels in the theca cells and androstenedione levels in the spent media were also determined.

\section{Antibodies}

Rabbit polyclonal anti-phospho-Akt (i.e. active Akt) antibodies and anti-total-Akt antibodies were purchased from Cell Signaling Technologies (Beverly, MA). Goat anti-rabbit IgG coupled to horseradish peroxidase was purchased from Santa Cruz Biotechnology, Inc. (Santa Cruz, CA).

\section{Reagents}

Human LH was provided by the National Institutes of Health and Dr. A. F. Parlow (National Hormone and Peptide Program, Torrance, CA). LY294002 (a PI3K inhibitor) was from Sigma Chemical Co. (St. Louis, MO), and wortmannin (a PI3K inhibitor), H89 (a selective inhibitor of PKA), and U0126 (a potent MEK inhibitor) were purchased from Calbiochem Novabiochem Corp. (San Diego, CA).

\section{Theca cell culture}

Bovine ovaries were collected less than 15 min after slaughter at a local abattoir. The ovaries were placed in an ice-cold buffered salt solution and transferred to the laboratory less than $90 \mathrm{~min}$ after collection. The estrous cycle stage was determined morphologically, as described previously by Ireland et al [17]; only those ovaries with a regressing corpus luteum were used for this study. Theca cells were isolated from the ovaries under sterile condi- 
tions, as described previously [18]. Briefly, small antral follicles (2-4 mm diameter) with clear surfaces were cut into halves and theca interna removed in situ using fine forceps. Granulosa cells, together with part of the theca cell layer, were removed by scraping with a scalpel under a stereomicroscope. The resultant thin thecal layer was minced and subsequently treated with a Hanks'-HEPES buffer containing collagenase ( $2150 \mathrm{U} / \mathrm{ml}$, type 1; Sigma) and DNase (100 U/ml; Sigma), $0.4 \%$ (vol/vol) BSA, and $0.2 \%$ (wt/vol) glucose ( $\mathrm{pH} 7.4)$. Cell dissociation was allowed to continue for $30-60 \mathrm{~min}$ at $37^{\circ} \mathrm{C}$ with continuous stirring at $80 \mathrm{rpm}$ and $0.25 \%(\mathrm{wt} / \mathrm{vol})$ pancreatin (Sigma) in a Hanks'-HEPES buffer for $7 \mathrm{~min}$. Dispersed cells were washed three times. Cell viability, as determined using the trypan blue-dye exclusion test, was 90$93 \%$. Purity of the theca cell preparation used in this study was substantiated by the secretion of estradiol; prepared theca cells did not produce estradiol in the presence or absence of forskolin, whereas granulosa cells obtained from the same follicle secret significant (data not shown). Isolated theca cells were plated onto serum-coated dishes with serum-free medium for $36 \mathrm{~h}$. Then they were stimulated with $\mathrm{LH}(100 \mathrm{ng} / \mathrm{ml})$ for various durations $(0,5$ min, 20 min, 1 h, $2 \mathrm{~h}, 4 \mathrm{~h}, 6 \mathrm{~h}, 8 \mathrm{~h}, 12 \mathrm{~h}, 24 \mathrm{~h}$, and $48 \mathrm{~h}$ ). Preliminary data indicated that $100 \mathrm{ng} / \mathrm{ml}$ of LH is the minimal effective concentration for inducing a significant increase in androgen production and CYP17A1 expression in our culture system.

\section{Western blot analysis}

Western blot analysis was conducted as described previously [12]. Briefly, primary cultures at the end of incubation with the appropriate stimulant or no stimulation as indicated in each experiment were rinsed with ice-cold PBS and once with buffer A $50 \mathrm{mM} \beta$-glycerophosphate (pH 7.3), 1.5 mM EGTA, 1 mM EDTA, 1 mM dithiothreitol, and $0.1 \mathrm{mM}$ sodium vanadate] and were subsequently harvested in buffer A plus proteinase inhibitors. Cell lysates were centrifuged at $20,000 \times g$ for $20 \mathrm{~min}$. The supernatant was assayed for protein content and subjected to Western blot analysis to detect anti-phospho-Akt and anti-total-Akt. Samples containing equal amounts of protein $(40 \mu \mathrm{g})$ were separated by $10 \%$ acrylamide SDSPAGE. The relevant proteins were detected on blots using their specific antibodies.

\section{Determination of androstenedione levels}

Androstenedione levels were determined using EIA at the end of the stimulation. Protein was quantified using the Bradford method.

\section{RNA extraction and RT-PCR}

Total RNA was isolated using TRIzol (Invitrogen Corp., Carlsbad, CA) according to the manufacturer's instructions. The RNA pellets were ethanol precipitated, washed, and resuspended in sterile ribonuclease-free water. Qual- ity of the RNA was assessed by fractionating it on 1\% agarose gel and observing the presence of the typical $28 \mathrm{~S}$ and $18 \mathrm{~S}$ rRNA under UV light. RT-PCR analyses for bovine CYP17A1, StAR, and 36B4 (an acidic ribosomal phosphoprotein as an internal control) were performed on total RNAs from cultured theca cells using specific primers. Primers used for bovine CYP17A1 were 5'-TCAGAGAAGTGCTCCGAATCC-3' and 5'-TGCCACTCCTTCTCACTGTGA-3'; those for bovine StAR were 5'TCGCGGCTCTCTCCTAGGT-3' and 5'-CTGCCGGCTCTCCTTCTTC-3', and those for bovine 36B4 were 5'GGCGACCTGGAAGTCCAACT-3' and 5'-GGATCTGCTGCATCTGCTTG-3', respectively. In each case, RNAs were reverse transcribed in a final volume of $40 \mu \mathrm{l}$ solution containing $1 \times$ first-strand buffer $\left[3 \mathrm{mM} \mathrm{MgCl}_{2}, 75 \mathrm{mM} \mathrm{KCl}\right.$, $50 \mathrm{mM}$ Tris- $\mathrm{HCl}$ (pH 8.3)], $500 \mu \mathrm{M}$ each deoxynucleotide triphosphate, $10 \mathrm{mM}$ dithiothreitol, 200 U SuperScript III RNase H-free reverse transcriptase (Invitrogen Corp.), 200 ng random hexamers, and $2 \mu \mathrm{g}$ total RNA. The target cDNAs were amplified for 30 cycles (CYP17A1 and StAR) and 25 cycles (36B4, internal control), respectively, in a thermal cycler ( $94 \mathrm{C}$ for $20 \mathrm{~s}, 60 \mathrm{C}$ for $30 \mathrm{~s}$, and $72 \mathrm{C}$ for $60 \mathrm{~s})$ using deoxynucleotide triphosphate $(0.2 \mathrm{mM})$ and 1.5 U of TaKaRa Ex Taq (Takara Shuzo Co. Ltd., Kyoto, Japan). Aliquots of PCR products were electrophoresed on $1.5 \%$ agarose gels and stained with ethidium bromide. The relative integrated density of each band was scanned and digitized using FluorChem (Alpha Innotech Corporation, San Leandro, CA); the ratios of densitometric readings of the amplified target cDNA and internal control, 36B4, DNA were analyzed.

\section{Statistical analysis}

All experiments were repeated at least three times using theca cells obtained from separate groups of bovines. Data were subjected to ANOVA. Group means were contrasted using Tukey's post hoc multiple comparison test. $P<0.05$ was considered significant. All values are expressed as mean \pm SEM.

\section{Results \\ Experiment I}

$\mathrm{LH}$ increases phospho-Akt content in bovine theca cells

Total-Akt was present in theca cells at $0 \mathrm{~h}$ and remained constant during culture with LH. During the $5 \mathrm{~min}$ to $8 \mathrm{~h}$ of culture, Akt was not phosphorylated by LH. However, the amount of phospho-Akt began to increase at $12 \mathrm{~h}$ and reached its highest level (five-fold higher than baseline) at $24 \mathrm{~h}$ after addition of LH (Fig. 1).

\section{Experiment 2}

Effects of the PI3K inhibitors on $\mathrm{LH}$-induced androgen production in theca cells

Results show that LH significantly increased androstenedione production in bovine theca cells. Addition of the PI3K inhibitors wortmannin and LY294002 significantly 

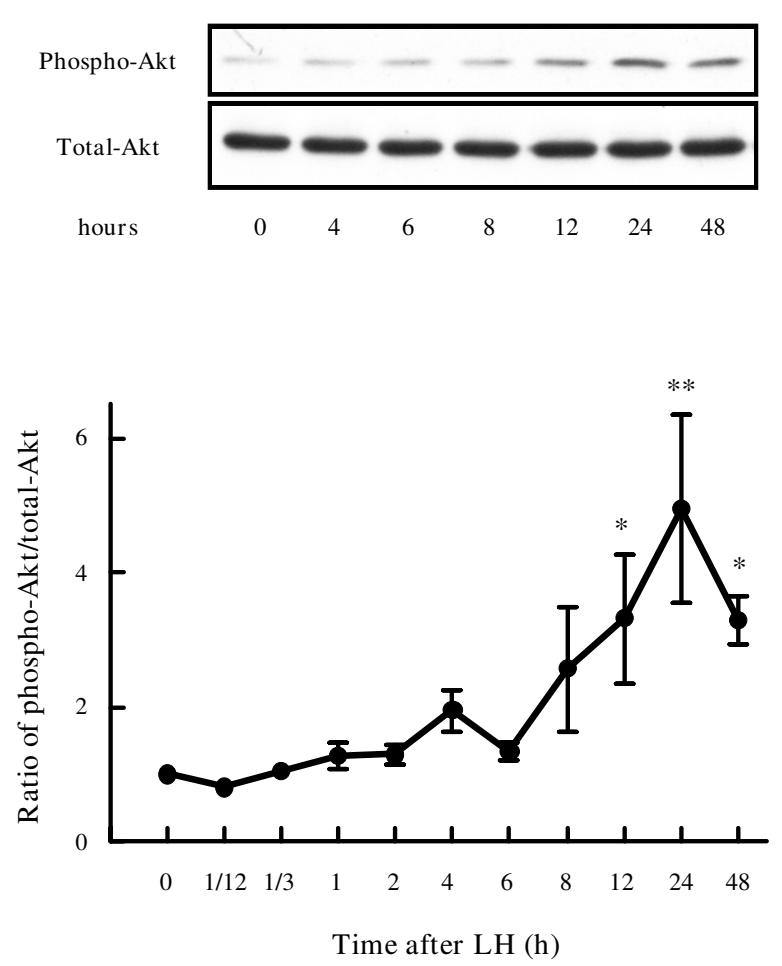

Figure I

Time-course effect of LH on Akt phosphorylation in bovine theca cells. Theca cells were plated onto serumcoated dishes with serum-free medium for $36 \mathrm{~h}$ and then stimulated with $\mathrm{LH}(100 \mathrm{ng} / \mathrm{ml})$ for the stated times.

Cytosolic extracts $(20 \mu \mathrm{g})$ were subjected to immunoblotting with anti-phosphorylated-Akt antibody and anti-total-Akt antibody. Representative images (Top) and densitometric data of phospho-Akt contents (Bottom), expressed as ratio of phospho-Akt to total-Akt, are shown. * denotes means that are significantly different from $0 \mathrm{~h}(P<0.0 \mathrm{l})$. ** denotes means that are significantly different from $0 \mathrm{~h}(P<0.00 \mathrm{I})$.

decreased LH-induced androstenedione production in theca cells (Fig. 2).

\section{Experiment 3}

Effects of the PI3K inhibitors on CYPI 7 and StAR mRNA expressions in theca cells

Results show that LH significantly increased CYP17A1 mRNA level in the theca cells. Addition of LY294002, but not wortmannin, significantly decreased LH-induced CYP17A1 mRNA expression (Fig. 3). Neither LH nor the PI3K inhibitors alter the mRNA levels of StAR in the theca cells.

\section{Experiment 4}

Effect of PKA inhibitor and MEK inhibitor on $\mathrm{LH}$-induced Akt phosphorylation

In fact, H89 (i.e. a selective inhibitor of PKA) did not affect LH-mediated changes in Akt. On the other hand,

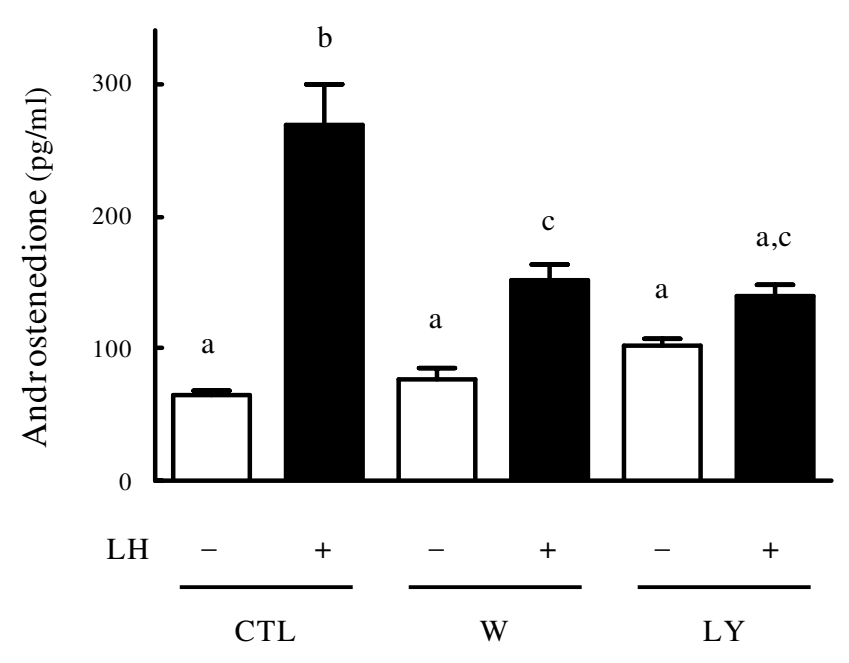

Figure 2

Effects of PI3K inhibitors on androstenedione production in bovine theca cells. Bovine theca cells were stimulated with LH (I00 ng/ml), wortmannin (W, $0.1 \mu \mathrm{M})$, LY294002 (LY, $25 \mu \mathrm{M})$, or their combination for $24 \mathrm{~h}$ in serum-coated dishes with serum-free medium. Control cells (CTL) were cultured in the absence of added treatments. Culture media were assayed for androstenedione by EIA. Values are means \pm SEM for four experiments. Different letters denote a significant difference of means $(P<0.05)$.

U0126 (i.e. a potent MEK inhibitor) inhibited LHinduced Akt phosphorylation in the theca cells (Fig. 4).

Although LH stimulated CYP17A1 mRNA expression and androstenedione production in the theca cells, the MAPK cascade inhibitor (U0126) completely blocked these responses (Fig. 5).

\section{Discussion}

In this study, we demonstrated that: 1) Akt is constitutively expressed, but is gradually phosphorylated in cultured bovine theca cells through exposure to $\mathrm{LH} ; 2$ ) $\mathrm{LH}$ stimulated androstenedione production in theca cells, although addition of the PI3K inhibitors (i.e. wortmannin and LY294002) attenuated LH-induced androstenedione production; 3) LH increased CYP17A1 mRNA level in theca cells, whereas addition of LY294002 suppressed LHinduced CYP17A1 expression in theca cells; 4) although H89 (i.e. a selective inhibitor of PKA) did not affect LHmediated changes in Akt, U0126 (i.e. a potent MEK inhibitor) inhibited the LH-induced Akt phosphorylation, CYP17A1 expression, and androgen production in theca cells. These results suggest that LH stimulates CYP17A1 mRNA expression and androgen production in theca cells via activation of the PI3K/Akt pathway, and that the MAPK, not PKA, is involved in LH stimulation of the PI3K/Akt cascade in bovine theca cells. 

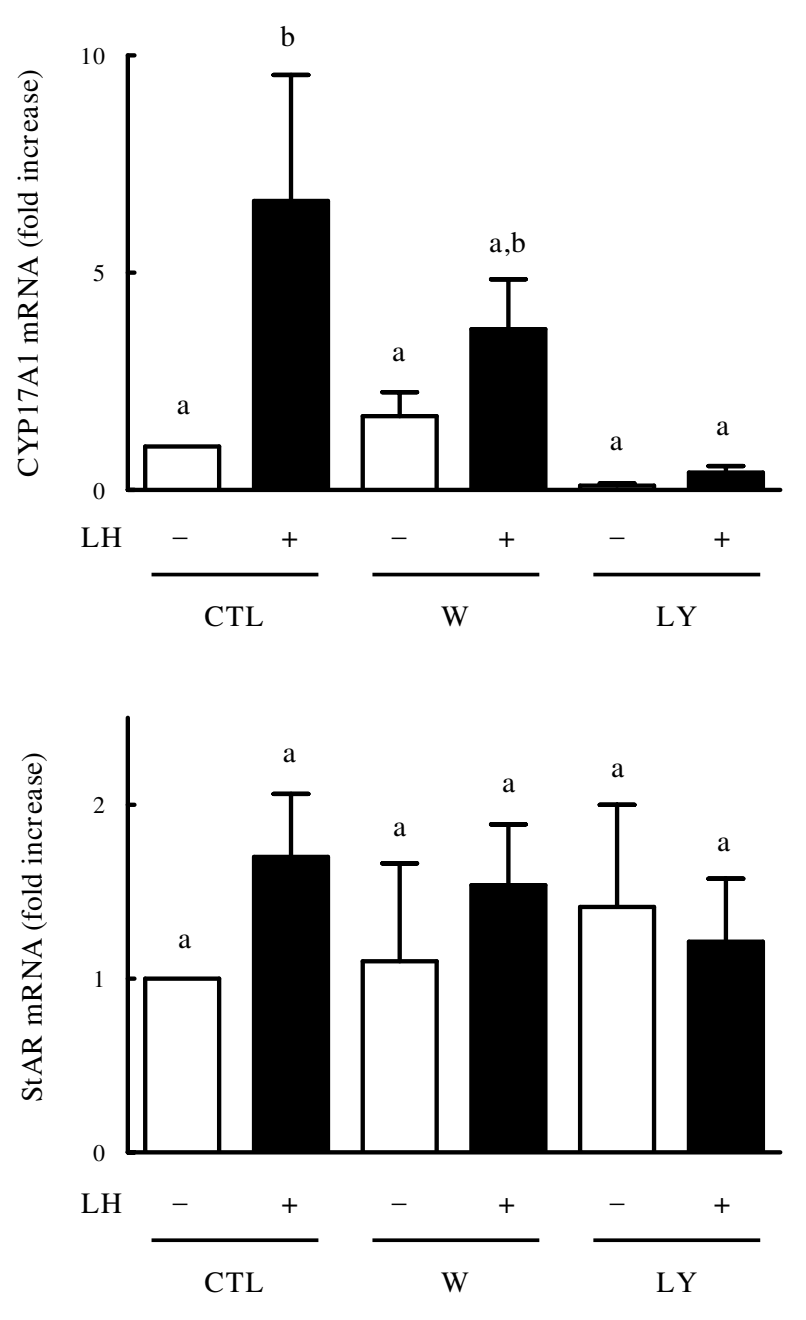

Figure 3

Effects of PI3K inhibitors on mRNA expression of CYPI7AI and StAR in bovine theca cells. Theca cells were incubated with $\mathrm{LH}$ in the presence or absence of wortmannin $(0.1 \mu \mathrm{M})$ or LY294002 $(25 \mu \mathrm{M})$ in serum-coated dishes with serum free medium for $12 \mathrm{~h}$. Control cells (CTL) were cultured in the absence of added treatments. Then RTPCR was conducted using CYPI7AI, StAR, and 36B4 (internal control) primers using total RNA isolated from the cells. The products were fractionated on $1 \%$ agarose gel and stained with ethidium bromide. The mRNA levels of CYPI7AI and StAR were expressed as ratio to 36B4 values. Data are the mean $\pm \operatorname{SEM}(n=5)$. Different letters represent statistically significant differences of means $(P<0.05)$.

PI3K converts phosphatidylinositol-4,5-biphosphate to phosphatidylinositol-3,4,5-triphosphate, leading to activation of downstream kinases including Akt, which in turn phosphorylates Bad, forkhead in rhabdomyosarcoma (FKHR), Fas-associated death domain-like IL-1 $\beta$ converting enzyme-like inhibitory protein (FLIP), and Xlinked inhibitor of apoptosis protein (XIAP) [19]. The
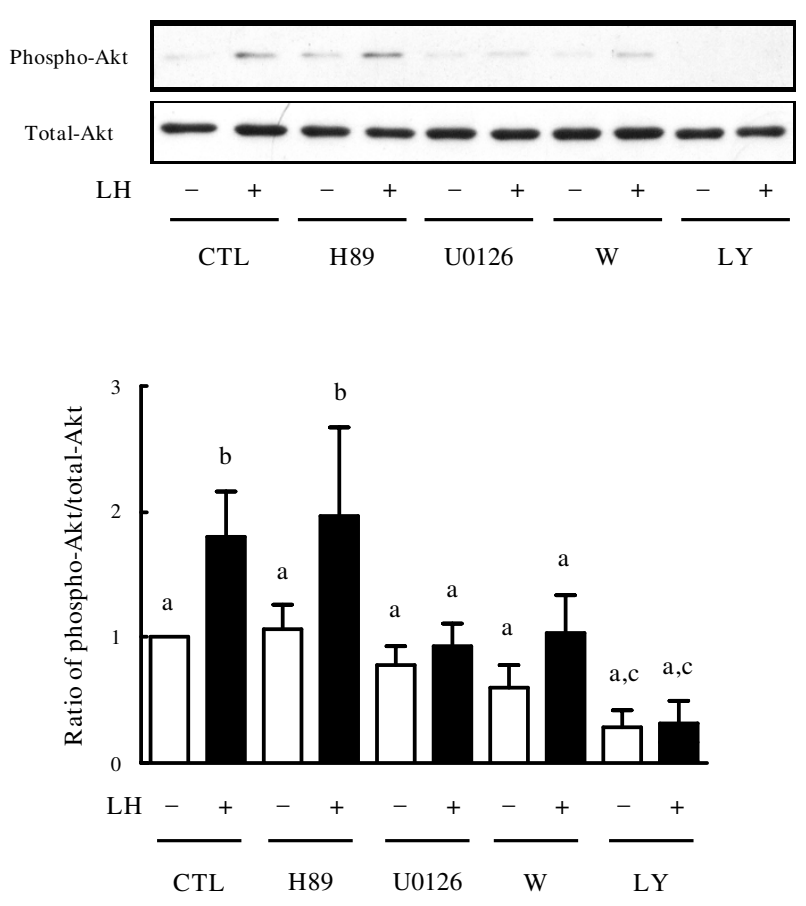

Figure 4

Effects of PKA inhibitor, MEK inhibitor and PI3K inhibitors on Akt phosphorylation in bovine theca cells. Subconfluent cultures were pretreated with PKA inhibitor (H89, $3 \mu \mathrm{M})$, MEK inhibitor (U0I26, $10 \mu \mathrm{M})$, or PI3K inhibitors (wortmannin, 0.I $\mu \mathrm{M}$; LY294002, $25 \mu \mathrm{M}$ ) for 30 $\mathrm{min}$. Then they were stimulated with $\mathrm{LH}(100 \mathrm{ng} / \mathrm{ml})$ for 24 h. Control cells (CTL) were cultured in the absence of added treatments. Cell lysates $(20 \mu \mathrm{g})$ were subjected to SDSPAGE and Western blot using anti-phosphorylated-Akt antibody (Phospho-Akt) or anti-total-Akt antibody (Total-Akt). Representative images (Top) and densitometric data of phospho-Akt contents (Bottom), expressed as a ratio of phosphoAkt to total-Akt, are shown. Values show the mean \pm SEM for three experiments. Each experiment was reproduced at least three times. Different letters denote significant differences of means $(P<0.05)$.

PI3K/Akt activation drives cell through many biological functions, including gene expression, cell cycle, survival, glucidic metabolism, endocytosis and vesicular trafficking, cell transformation, and oncogenesis [20]. In ovary, FSH and several growth factors are known to activate the PI3K/Akt pathway and prevent apoptosis in granulosa cells and cultured follicles [13-15]. Although LH has been reported to activate the CAMP/PKA pathway [4] and the ERK/MAPK pathway [12] in theca cells, whether LH stimulates the PI3K/Akt cascade in theca cells remains unclear. Results of this study show for the first time that 1) LH stimulates Akt phosphorylation in cultured bovine theca cells, and that 2) activation of PI3K/Akt is involved in CYP17A1 mRNA expression and androgen production in 


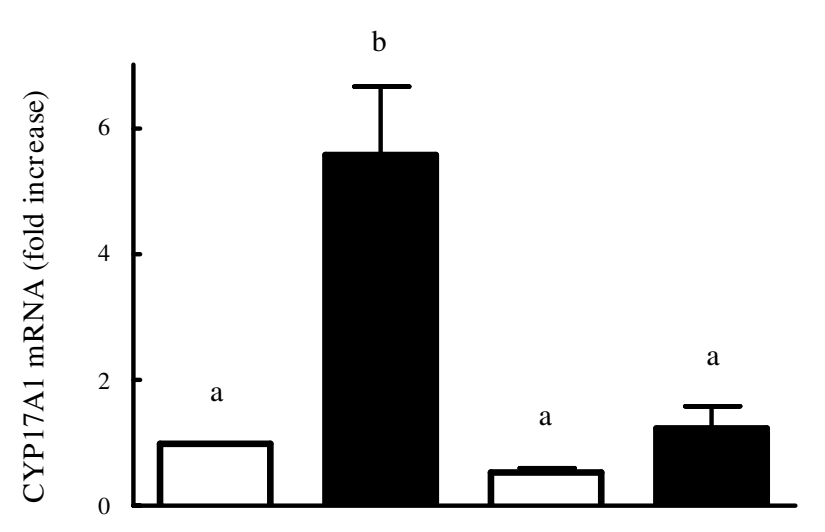

$\mathrm{LH}$

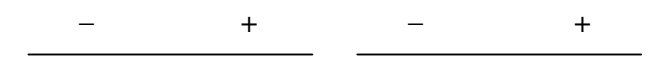

CTL

U0126

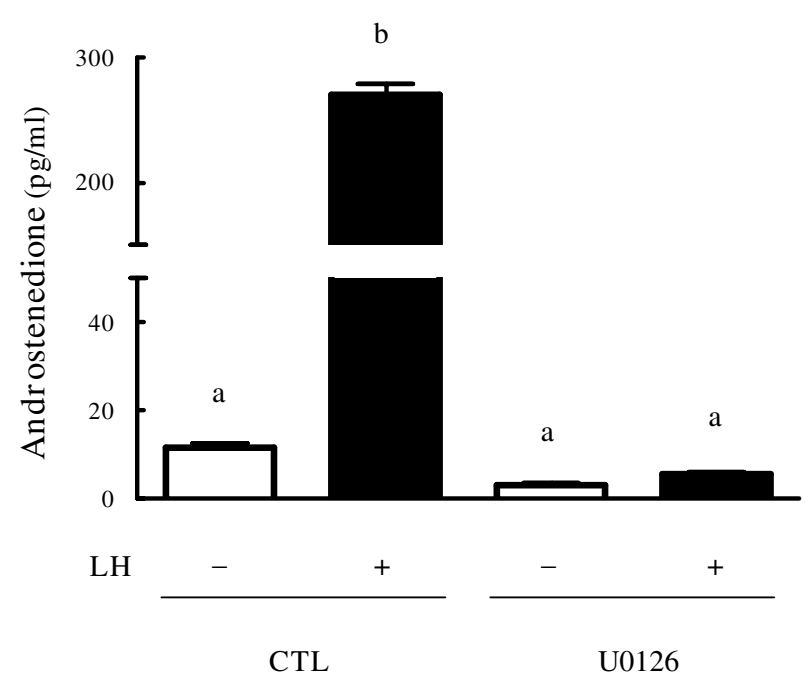

Figure 5

Effects of MEK inhibitor on CYPI7AI mRNA expression and androstenedione production in bovine theca cells. Subconfluent cultures were pretreated with MEK inhibitor (U0I26, $10 \mu \mathrm{M})$ for $30 \mathrm{~min}$. Then they were stimulated with $\mathrm{LH}(100 \mathrm{ng} / \mathrm{ml})$ for I 2-24 h. Control cells (CTL) were cultured in the absence of added treatments. RT-PCR was conducted using CYPI7AI and 36B4 (internal control) primers using total RNA isolated from the cells. The mRNA level of CYPI7AI were expressed as ratio to 36B4 values (Top). Culture media were also assayed for androstenedione by EIA (Bottom). Data are the mean $\pm \operatorname{SEM}(n=4)$. Each experiment was reproduced at least three times. Different letters represent statistically significant differences of means $(P<$ 0.05).

theca cells. Reportedly, LH induced Akt phosphorylation in whole rat ovary [21], and the PI3K inhibitor, LY294002, suppressed androstenedione production by theca cells in rat [22] and cattle [11]. It is possible that LH- stimulated Akt phosphorylation in theca cells is responsible for these observations reported earlier.

Both wortmannin and LY294002 are inhibitors of the lipid-modifying enzymes known as PI3K, and many researchers perform a parallel study by using both inhibitors to probe the roles of PI3K in biological processes. However, depending on the concentration examined, these inhibitors could be non-specific and cytotoxic and could complicate the interpretation of their findings. In our system, the $0.1 \mu \mathrm{M}$ of wortmannin and $25 \mu \mathrm{M}$ of LY294002 are the minimal effective concentrations for blocking the LH-induced androstenedione production in theca cells. Nevertheless, only LY294002 suppressed LHinduced CYP17A1 mRNA expression, whereas wortmannin did not affect this response. While the reason for this apparent discrepancy is not clear, it is worth noting that wortmannin has been reported to be unstable in aqueous solution and less specific than LY294002 [23,24]. Higher concentration $(>0.1 \mu \mathrm{M})$ of wortmannin induced theca cell detachment and apoptosis in our serum-free culture system.

Numerous reports have described that an activation of the intracellular signaling (i.e. CAMP/PKA, ERK/MAPK, and $\mathrm{PI} 3 \mathrm{~K} / \mathrm{Akt}$ ) is a rapid reaction in most cells. However, in this study, it took $12 \mathrm{~h}$ for LH-induced increase in phospho-Akt content in theca cells. It is of interest whether PKA pathway, which is considered to be a major mediator of the LH-generated signaling, and/or the MAPK pathway influence LH-induced Akt phosphorylation or not. Experiment 4 was performed to verify this point.

As described earlier, H89, a potent and selective inhibitor of PKA, did not affect LH-mediated changes in phosphoAkt, indicating that a pathway distinct from that of PKA is involved in LH-induced Akt phosphorylation in theca cells. Until recently, the effects of cAMP were generally thought to be mediated by activation of cAMP-dependent PKA, a major CAMP target, followed by phosphorylation of many intracellular targets, such as cAMP responsive element binding protein (CREB) [25], resulting in changes in ovarian gene expression such as CYP17A1. Nevertheless, some effects of CAMP appear to be inexplicable by activation of PKA. For instance, TSH and cAMP regulate proliferation of thyroid cells by mechanisms independent of PKA [26-29]. Actually, cAMP binds specific guanine nucleotide exchange factors: cAMP-GEFs (also called exchange protein activated by cAMP, Epac) [30,31]. GonzalezRobayna et al. reported that cAMP-GEFs are expressed in rat granulosa cells and that the CAMP-GEFs play a role in FSH-induced activation of the PI3K/Akt pathway in granulosa cells by PKA-independent manner [32]. Whether theca cells also express these regulatory components and whether the (PKA-independent) CAMP-GEFs mechanism 
is involved in LH-induced Akt phosphorylation in theca cells remains to be elucidated.

In contrast to PKA inhibitor, the MEK inhibitor (U0126) blocked LH-mediated Akt phosphorylation and androgen production in theca cells. Reportedly, the MAPK inhibitor also inhibits FSH-mediated Akt phosphorylation in rat granulosa cells [32]. While the precise mechanism for the activation of PI3K pathway by LH in theca cells is not known, it is possible that the LH-induced phospho-Akt up-regulation may involve MAPK-mediated down-regulation of phosphatase and tensin homologue (PTEN; a tumor suppressor which negatively regulates Akt phosphorylation). In this context, it has been shown that PI3K is required for estradiol-stimulated hepatic cell growth and that the MAPK pathway reduces the level of PTEN, allowing estradiol-induced phosphorylation of Akt [20]. Whether this indeed is the case in the theca cells awaits further investigation.

As a mechanism explaining why phospho-Akt content in theca cells was increased only after $12 \mathrm{~h}$ of incubation with LH, we are also interested in autocrine effects of insulin-like growth factor-II (IGF-II) and nerve growth factor (NGF) on theca cells. Reportedly, theca cells express IGFII and NGF in cattle, and each of IGF-II and NGF stimulate androgen production $[33,34]$. Whether LH induces gene/ protein expression of these growth factors, and whether it modulates the LH-mediated Akt phosphorylation in theca cells, are subjects that are currently under investigation in our laboratory.

\section{Conclusion}

Taking this evidence together, we conclude that LH stimulates CYP17A1 mRNA expression and androgen production in theca cells via activation of the PI3K/Akt pathway. LH acts in theca cells by PKA-independent mechanisms as well as PKA-dependent mechanisms, each of which controls androgen production. Both the PI3K and the MAPK pathways coordinately regulate androgen production in bovine theca cells. Clarification of the LH-mediated intracellular signaling events is essential for better understanding of not only ovarian physiology, but also of the pathophysiology of PCOS.

\section{Abbreviations}

LH: luteinizing hormone; cAMP: cyclic adenosine monophosphate; PKA: protein kinase A; CYP17A1: $17 \alpha$-hydroxylase/C17-20 lyase cytochrome P450; StAR: steroidogenic acute regulatory protein; ERK: extracellular-signal regulated kinase; MAPK: mitogen activated protein kinase; PI3K: phosphatidyl inositol 3-kinase; EIA: enzyme immunoassay; RT-PCR: reverse transcription polymerase chain reaction; MEK: MAPK/ERK kinase; 36B4: acidic ribosomal phosphoprotein; GEFs: guanine nucleotide exchange fac- tors; PTEN: phosphatase and tensin homologue; PCOS: polycystic ovary syndrome.

\section{Competing interests}

The authors declare that they have no competing interests.

\section{Authors' contributions}

$\mathrm{SF}, \mathrm{MO}, \mathrm{KT}, \mathrm{KH}$, and FK conceived of the study, participated in its design and coordination and drafted the manuscript. All authors read and approved the final version of the manuscript.

\section{Acknowledgements}

This research was supported by a Grant-in-Aid for Scientific Research from the Ministry of Education, Culture, Sports, Science, and Technology, Japan (MEXT; Grant 19591892 and 21592093 to M.O.).

\section{References}

I. Erickson GF, Magoffin DA, Dyer CA, Hofeditz C: The ovarian androgen producing cells: a review of structure/function relationships. Endocr Rev 1985, 6:37|-99.

2. Weil SJ, Vendola K, Zhou J, Adesanya OO, Wang J, Okafor J, Bondy $C A$ : Androgen receptor gene expression in the primate ovary: cellular localization, regulation, and functional correlations. J Clin Endocrinol Metab 1998, 83:2479-85.

3. Hu YC, Wang PH, Yeh S, Wang RS, Xie C, Xu Q, Zhou X, Chao HT, Tsai MY, Chang C: Subfertility and defective folliculogenesis in female mice lacking androgen receptor. Proc Natl Acad Sci USA 2004, I I I: I I 209-14.

4. Magoffin DA: Ovarian theca cell. Int J Biochem Cell Biol 2005, 37:1344-9.

5. Erickson GF, Ryan KJ: Stimulation of testosterone production in isolated rabbit thecal tissue by LH/FSH, dibutyryl cyclic AMP, PGE2alpha, and PGE2. Endocrinology 1976, 99:452-8.

6. Richards JS, Hedin L, Caston L: Differentiation of rat ovarian thecal cells: evidence for functional luteinization. Endocrinology 1986, I I 8:1660-8.

7. Bogovich K, Richards JS: Androgen biosynthesis in developing ovarian follicles: evidence that luteinizing hormone regulates thecal 17 alpha-hydroxylase and C 17-20-lyase activities. Endocrinology 1982, I I I: | 20I-8.

8. Magoffin DA, Kurtz KM, Erickson GF: Insulin-like growth factor-I selectively stimulates cholesterol side-chain cleavage expression in ovarian theca-interstitial cells. Mol Endocrinol 1990, 4:489-96.

9. Magoffin DA, Weitsman SR: Differentiation of ovarian thecainterstitial cells in vitro: regulation of 17 alpha-hydroxylase messenger ribonucleic acid expression by luteinizing hormone and insulin-like growth factor-I. Endocrinology 1993, 132: 1945-5I.

10. Magoffin DA, Weitsman SR: Insulin-like growth factor-I stimulates the expression of 3 beta-hydroxysteroid dehydrogenase messenger ribonucleic acid in ovarian theca-interstitial cells. Biol Reprod 1993, 48: I 166-73.

II. Ryan KE, Glister C, Lonergan P, Martin F, Knight PG, Evans AC: Functional significance of the signal transduction pathways Akt and Erk in ovarian follicles: in vitro and in vivo studies in cattle and sheep. J Ovarian Res 2008, I:2.

12. Tajima K, Yoshii K, Fukuda S, Orisaka M, Miyamoto K, Amsterdam A, Kotsuji F: Luteinizing hormone-induced extracellular-signal regulated kinase activation differently modulates progesterone and androstenedione production in bovine theca cells. Endocrinology 2005, I46:2903-10.

13. Tilly JL, Pru JK, Rueda BR: Apoptosis in ovarian development, function, and failure. The ovary 2 nd edition. 2004:32I-52.

14. Hu CL, Cowan RG, Harman RM, Quirk SM: Cell cycle progression and activation of Akt kinase are required for insulin-like growth factor I-mediated suppression of apoptosis in granulosa cells. Mol Endocrinol 2004, 18:326-38. 
15. Orisaka M, Orisaka S, Jiang JY, Craig J, Wang Y, Kotsuji F, Tsang BK: Growth differentiation factor 9 is antiapoptotic during follicular development from preantral to early antral stage. Mol Endocrinol 2006, 20:2456-68.

16. Hidaka $\mathrm{H}$, Watanabe M, Kobayashi R: Properties and use of $\mathbf{H -}$ series compounds as protein kinase inhibitors. Methods Enzymol 199I, 201:328-39.

17. Ireland JJ, Murphee RL, Coulson PB: Accuracy of predicting stages of bovine estrous cycle by gross appearance of the corpus luteum. J Dairy Sci 1980, 63:155-60.

18. Tajima K, Orisaka M, Hosokawa K, Amsterdam A, Kotsuji F: Effects of ovarian theca cells on apoptosis and proliferation of granulosa cells: changes during bovine follicular maturation. Biol Reprod 2002, 66:1635-9.

19. Franke TF, Kaplan DR, Cantley LC: PI3K: downstream AKTion blocks apoptosis. Cell 1997, 88:435-7.

20. Marino M, Acconcia F, Trentalance A: Biphasic estradiol-induced AKT phosphorylation is modulated by PTEN via MAP kinase in HepG2 cells. Mol Biol Cell 2003, I 4:2583-9I.

21. Carvalho CR, Carvalheira JB, Lima MH, Zimmerman SF, Caperuto LC, Amanso A, Gasparetti AL, Meneghetti V, Zimmerman LF, Velloso LA, Saad MJ: Novel signal transduction pathway for luteinizing hormone and its interaction with insulin: activation of Janus kinase/signal transducer and activator of transcription and phosphoinositol 3-kinase/Akt pathways. Endocrinology 2003, 144:638-47.

22. Zerbinatti CV, Mayer LP, Audet RG, Dyer CA: Apolipoprotein E is a putative autocrine regulator of the rat ovarian theca cell compartment. Biol Reprod 200I, 64:1080-9.

23. Vlahos CJ, Matter WF, Hui KY, Brown RF: A specific inhibitor of phosphatidylinositol 3-kinase, 2-(4-morpholinyl)-8-phenyl4H-I-benzopyran-4-one (LY294002). J Biol Chem 1994, 269:524I-8.

24. Stein RC, Waterfield MD: PI3-kinase inhibition: a target for drug development? Mol Med Today 2000, 6:347-57.

25. Gonzalez GA, Montminy MR: Cyclic AMP stimulates somatostatin gene transcription by phosphorylation of CREB at serine 133. Cell 1989, 59:675-80.

26. Cass LA, Summers SA, Prendergast GV, Backer JM, Birnbaum MJ, Meinkoth JL: Protein kinase A-dependent and -independent signaling pathways contribute to cyclic AMP-stimulated proliferation. Mol Cell Biol 1999, 19:5882-91.

27. Dremier S, Pohl V, Poteet-Smith C, Roger PP, Corbin J, Doskeland SO, et al: Activation of cyclic AMP-dependent kinase is required but may not be sufficient to mimic cyclic AMP. dependent DNA synthesis and thyroglobulin expression in dog thyroid cells. Mol Cell Biol 1997, 17:6717-26.

28. Kupperman E, Wen W, Meinkoth JL: Inhibition of thyrotropinstimulated DNA synthesis by microinjection of inhibitors of cellular Ras and cyclic AMP-dependent protein kinase. Mol Cell Biol 1993, 13:4477-84.

29. Cass LA, Meinkoth JL: Differential effects of cyclic adenosine 3',5'-monophosphate on p70 ribosomal S6 kinase. Endocrinology 1998, 139:1991-8.

30. de Rooij J, Zwartkruis FJ, Verheijen MH, Cool RH, Nijman SM, Wittinghofer A, Bos JL: Epac is a Rapl guanine-nucleotideexchange factor directly activated by cyclic AMP. Nature 1998, 396:474-7.

31. Kawasaki H, Springett GM, Mochizuki N, Toki S, Nakaya M, Matsuda M, Housman DE, Graybiel AM: A family of cAMP-binding proteins that directly activate Rap I. Science 1998, 282:2275-9.

32. Gonzalez-Robayna IJ, Falender AE, Ochsner S, Firestone GL, Richards JS: Follicle-Stimulating hormone (FSH) stimulates phosphorylation and activation of protein kinase B (PKB/Akt) and serum and glucocorticoid-Induced kinase (Sgk): evidence for A kinase-independent signaling by FSH in granulosa cells. Mol Endocrinol 2000, I 4: 1283-300.

33. Spicer LJ, Voge JL, Allen DT: Insulin-like growth factor-II stimulates steroidogenesis in cultured bovine thecal cells. Mol Cell Endocrinol 2004, 227: I-7.

34. Dissen GA, Parrott JA, Skinner MK, Hill DF, Costa ME, Ojeda SR: Direct effects of nerve growth factor on thecal cells from antral ovarian follicles. Endocrinology 2000, 141:4736-50.

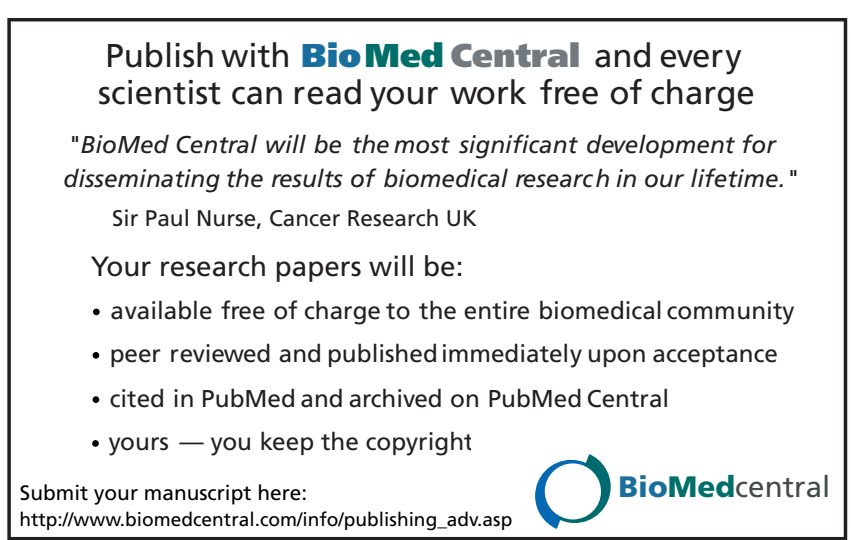

